\title{
細胞内の張力を測定する
}

\section{Sensing tension}

Andrew D. Doyle And Kenneth M. Yamada 2010 年 7 月 8 日号 Vol. 466 (192-193)

生きている細胞で、特定の部位にかかっている張力を測定するのは、技術的にたいへん難しい。

今回、蛍光の変化で張力を測定できるバイオセンサーを細胞内タンパク質で実現し、

移動している細胞で生じる張力の、局所的変化の特徵が調べられた。

細胞は、常に分子間力を利用してい る ${ }^{1-3}$ 。例えば、構造の一部の突出と収 縮をうまく連動させて、移動や浸潤を 行っているし、収縮張力を利用して、ほ かの細胞や細胞外マトリックスに安定的 に接着することもできる ${ }^{4}$ 。また、分裂 するためには、細胞内の複数の力を調整 しなければならない。しかし、1 個の細 胞の内部で生じるこのような複雑な張力 を、測定したりマッピングしたりするの は技術的に難しい。理想的なッールの 1 つは、機械的な力の計測器として機能す る小型の生物学的装置を、細胞内の局所 的な引つ張りや動きの生じる部位に埋め 込んだものだろう。Carsten Grashoff た ち ${ }^{5}$ は、個々の細胞内に生じる力をマッ ピングするのに威力を発揮するッール を開発し、Nature 2010 年 7 月 8 日号 263 ページで報告した。具体的にいうと、 彼らが開発したのは、動的な細胞接着構 造で生じている張力を正確に測定するた めの「第二世代」バイオセンサーだ。彼 らはそのセンサーを使って、局所的な力 が、細胞の移動に伴って実際にどのよう に変化するのかを明らかにした。

Grashoff たちはまず、バネ様のタンパ ク質部分を含む張力センサーモジュール を設計することから始めた。このバネ様 部分は、クモ糸のタンパク質に由来する アミノ酸配列を土台にしたもので、張力 に応じて伸びる性質をもっている。次に 彼らは、このバネ様タンパク質部分の両
端に蛍光タンパク質を付けた（図 la)。 張力がかかると、このセンサーモジュー ルが伸長し、両端の蛍光タンパク質の距 離が離れるので、蛍光の減少という形で

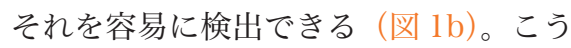
して、Grashoff たちはキメラ分子をたっ た 1 種類用いるだけで、局所張力の高感 度測定（ピコニュートンの単位）を可能 にしたのである。

研究チームは、この蛍光張力センサー モジュールを、ビンキュリンという細胞 内タンパク質に組み込んだ。このタンパ ク質は、細胞の接着や移動時に生じる 「力」に関連する機能をもつ。これはよ い選択だった。なぜなら、ビンキュリン の頭部ドメインはテーリン（細胞外マト リックスと相互作用する細胞表面接着受 容体に結合するタンパク質）に結合し、 尾部ドメインはアクチン細胞骨格に結合 するからだ (図 1b)。つまり、ビンキュ リンは細胞の内外間の張力変化を検出す るのに適役なのだ。ビンキュリンがアク チン細胞骨格と細胞表面接着受容体の間 で伸長すると、そこに組み込まれた張力 センサーモジュールによって、移動して いる細胞の内部で張力が変化している位 置を特定でき、変化の程度を測定できる のである。

このバイオセンサーのおかげで Grashoff たちは、培養組織内を移動す る細胞が形成した接着斑とよばれる細胞 接着構造での張力を、初めて直接測定す
ることができたのだ。研究チーム ${ }^{5}$ は、 細胞が移動するときに、細胞の前端で新 たに形成された接着では、ビンキュリン にかかる張力が大きく、接着面から解離 する細胞の後端では、張力が小さくなる ことを見つけた。この観察結果は、これ まで考えられていた、移動の際に生じる 細胞内の張力の非対称性を、エレガント かつ直接的に定量化したものだ。また、 細胞内で、分子モーターのミオシンに駆 動されるアクチンフィラメントの収縮を 阻害すると、予想どおり、ビンキュリン にかかる張力は消失した。

このバイオセンサーを使って、もう 1 つの洞察が得られた。それは、接着部位 にビンキュリンが誘導される機能は、ビ ンキュリンの「細胞内の力を伝達する能 力」とは無関係だということだ。さらに、 ビンキュリンがない条件下では、強い力 によって細胞接着の解離が起こることか ら、ビンキュリンは、細胞接着の安定性 維持に役立つているものと考えられる。

Grashoff たちが今回開発したプローブ 分子は、初めての張力バイオセンサーと いうょり、生物学的な力を検出する技術 として最先端を行くものだと表現したほ うがいいだろう。概念的にこれと似た方 法は既に存在し、フィブロネクチンとい う細胞外タンパク質で、張力による伸長 を測定するために使われている ${ }^{6}$ 。ほか にも張力バイオセンサーが設計されてい る。アクチン結合タンパク質である $\alpha$ - 
アクチニンにかかるカが、移動中の細胞 の前端と後端部分で異なることが報告さ れたり ${ }^{7}$ 、生きている細胞でアクチン ミオシン結合の張力の大きさが決定され

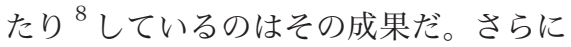
もう 1 つ、線虫 (C. elegans) で発現させ ることに成功した張力バイオセンサーが

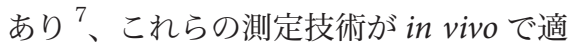
用可能だろうと示唆されていたのだ。

タンパク質の中には、力を感知し、応 答する能力を本来備えているものがある ことも、既に明らかになっている。例え ば、膜にある一部のイオンチャネルは 引き伸ばしによって活性化され、また、 テーリンはカによって活性化されてビ ンキュリン ${ }^{9}$ やシグナル伝達タンパク質 p130Cas に結合し、下流のリン酸化や シグナル伝達を促進する ${ }^{10}$ 。しかし、今 回のビンキュリン製バイオセンサー ${ }^{5}$ が 特別なのは、局所の力をマッピングする のに必要な、高感度かつ高精度の定量化 ができる点である。この利点によって、 力に依存する生物学的プロセスの詳細な 研究が可能になるわけだ。

今回のような張力計測分子は、細胞内 に生じるさまざまな力を明確にできる可 能性を秘めている。例えば、細胞が有糸 分裂をするときに染色体を動かしたり 導いたりする力や、細胞が移動したり ニューロンの軸索突起が伸びたりすると きに細胞膜にかかる複雑で局所的な力を 測定することができるかもしれない。ま た、骨再形成や腫瘍細胞の浸潤における 力学的な特性などを調べることもできる かもしれない。ところで、こうした張力 センサーモジュールをほかのタンパク質 の一部に組み込んで、細胞のほかの部位 で使ったり、細胞内の別の種類の力を測 定するのに使ったりするというのは、ど れくらい現実的な話なのだろうか？

その答えは、ビンキュリンと共通する ある特定の条件を満たすような、重要な 特徴をもつタンパク質候補が見つけられ るかどうかにかかっているだうう。それ はまず、この張力センサーモジュールを 組み込む先のタンパク質が、測定対象の a

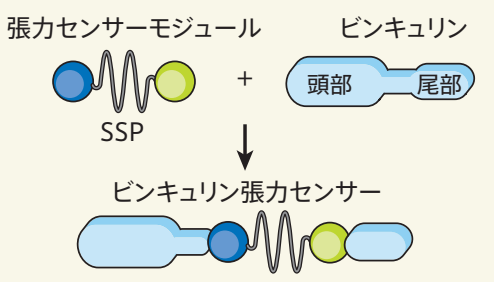

b

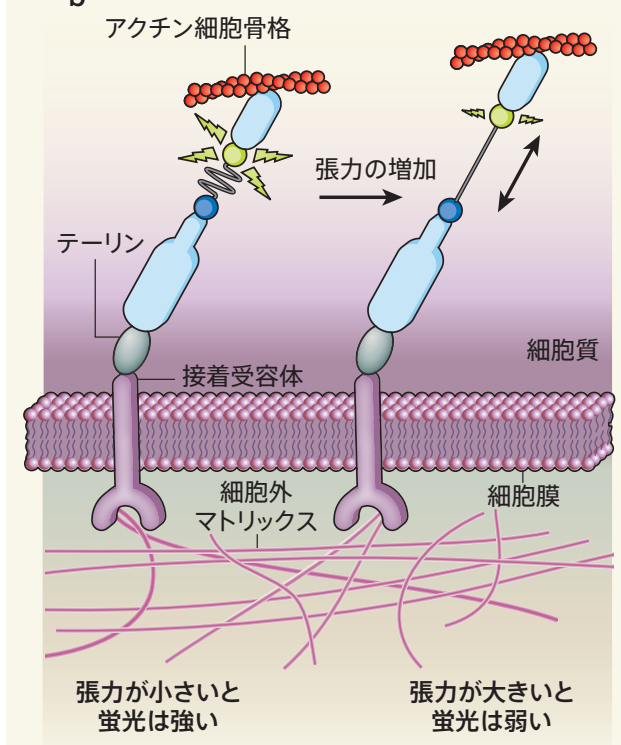

図 1. 張カバイオセンサー。a. Grashoff たち ${ }^{5}$ は、細胞で生じる局所的な力を測定 するための張カセンサーモジュールを設計 した。使用したのは、クモの横糸タンパク 質由来の、アミノ酸 40 個からなる伸縮性 のある部分（クモ糸タンパク質；SSP）で、 その両端に蛍光タンパク質（青色と緑色） を付けてある。このセンサーモジュールを、 ビンキュリンの頭部と尾部の間に組み込ん だ。b.このセンサーにかかる細胞張力が 増加するとSSP 領域が伸長し、両端にある 蛍光タンパク質が引き離されて、蛍光が減 少する（蛍光共鳴エネルギー移動：FRET による測定法と似た原理)。こうして蛍光の 変化を測定することで、張力を定量化する ことができる。c. 実際の細胞の観測例。

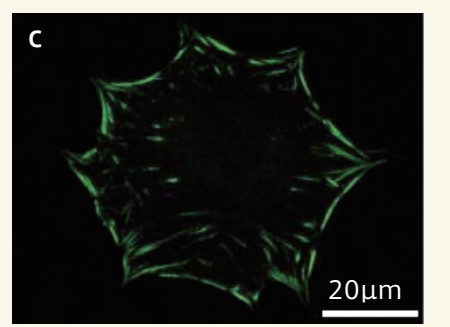

力によって伸長できるような細胞内の場 所に存在していることである。しかも、 センサーモジュールを組み込んだ後にも 機能を保持している必要がある。また逆 に、このタンパク質の機能がセンサーの 機能に影響を及ぼしてもいけない。もし、 このような張力センサーモジュールを組 み込むことのできる理想のタンパク質が 見つからなくても、2 種類のタンパク質 間もしくはこれらのタンパク質の結合部 位間にモジュールを置くことで、別の夕 イプのキメラ型力感知バイオセンサーを 実現できるかもしれない。また、もう 1 つの展開の仕方として考元られるのは、 力の検出感度を高めることだろう。今回 の手法 ${ }^{5}$ では、単一分子の力を検出する のではなく、特定部位の数百個の分子を 解析することで、力を検出している。

将来、張力バイオセンサーを体系的に 利用し、組織または動物個体の内部で生 じる力をそのまま測定できるようになれ ば、興味の対象は大きく広がる ${ }^{7}$ 。例えば、 in vivoでの細胞外マトリックス内部や、
細胞と細胞の間、1 個の細胞とその周囲 の結合組織の間などの場所で、胚の体制 が確立されるときや、発生中の器官で内 部構造が形作られている時期に、力を測 定するのである。局所の力を視覚化した り定量化したりすることができれば、遺 伝子やタンパク質の組織特異的な発現に 関する膨大な情報と、機能をもつ 1 個の 生物個体を作り上げている種々の力とを 結びつけることができ、生命の仕組みを 理解するのに役立つはずである。

(翻訳：船田晶子)

Andrew D. Doyle および Kenneth M. Yamada、 国立衛生研究所国立歯科·頭蓋顔面研究所(米国)。

1. Mofrad, M. R. K.\&Kamm, R. D.Cellular Mechanotransduction (Cambridge Univ. Press, 2009).

2. Vogel, V. \& Sheetz, M. Nature Rev. Mol. Cell Biol. 7, 265-275 (2006).

3. Orr, A. W., Helmke, B. P., Blackman, B. R. \& Schwartz, M. A. Dev. Cell 10, 11-20 (2006)

4. Ridley, A. J. et al. Science 302, 1704-1709 (2003)

5. Grashoff, C. et al. Nature 466, 263-266 (2010).

6. Klotzsch, E. et al. Proc. Natl Acad. Sci. USA 106, 18267-18272 (2009).

7. Meng, F., Suchyna, T. M. \& Sachs, F. FEBS J. 275, 3072-3087 (2008).

8. Iwai, S. \& Uyeda, T. Q. P. Proc. Natl Acad. Sci. USA 105, 16882-16887 (2008).

9. del Rio, A. et al. Science 323, 638-641 (2009).

10. Sawada, Y. et al. Cell 127, 1015-1026 (2006). 